\title{
CORRESPONDENCE
}

\section{Nerve Growth Factor}

SIR,-Drs Hendry and Iverson (Nature, 243, $500 ; 1973$ ) report that surgical excision of submaxillary salivary glands in adult mice causes a profound temporary drop in the plasma and tissue concentration of nerve growth factor, which was followed by a fairly rapid recovery to approximately normal plasma concentration. They postulated that an unidentified source of NGF must have been available which was capable of maintaining normal plasma concentrations. Furthermore, it is known that NGF is absent from the mouse sub- maxillary glands during foetal and preadolescent life and attempts to isolate it from the glands of animals other than the mouse have been unsuccessful, and yet it is essential for the growth in culture of both sympathetic and sensory ganglia of many species. It would, therefore, be expected that another source of NGF should be available to foetal and pre-adolescent mice and other species of animal. Last year (Exp. Cell Res., 74, $170 ; 1972$ ) we reported that fluorescent labelled anti-NGF stained intestinal mucosae of all the foetal and adult animals belonging to many species, including mice. In gel-diffusion the crude mouse intestinal homogenate produced two lines of precipitation against anti-NGF, one of which showed a reaction of identity with NGF. Although all our attempts to demonstrate nerve growth promoting activity in the crude homogenates were unsuccessful, it is possible that a sensitive assay technique like radioimmunoassay may be able to detect its presence in the intestine.

\section{Yours faithfully,}

\section{S. KUMAR}

Clinical Research Laboratories,

Christie Hospital,

Manchester

\section{Obituary}

\section{Mikhail Dmitrievich Millionshchikov}

ACADEMICIAN MikHaIL DMitrieVich MILLIONSHCHIKOV, vice-president of the Soviet Academy of Sciences, deputy director of the Kurchatov Institute of Atomic Energy, and a leading spokesman for the Soviet Union regarding scientific contacts with the West, died on May 27, 1973.

Millionshchikov was born on January 15, 1913, in Groznyi in the Caucasus. $\mathrm{He}$ was educated at the Groznyi Petroleum Institute, where he graduated in 1932. By the time he was twenty, he had already attracted considerable notice with his research on problems of the filtration of oil and gas through rocks. In 1934, he became an instructor at the Moscow Aviation Institute, where he remained until 1943. Here he carried out research into the theory of turbulence, working initially under the supervision of the mathematician Andrei N. Kolmogorov, and obtaining some now classic results.

In 1943 he became an instructor at the Moscow Institute of Engineering and Physics and worked simultaneously at the Institute of Mechanics of the Soviet Academy of Sciences. He joined the Soviet atomic energy programme in 1949, working at the Kurchatov Atomic Energy Institute on various aspects of nuclear engineering, notably the direct conversion of nuclear energy into elec- trical energy. In 1960, on Kurchatov's death, he became deputy director of the Institute, continuing his research on nuclear reactors, direct conversion technology and low temperature plasmas.

$\mathrm{He}$ was elected a full member of the Academy of Sciences in 1962, becoming a vice-president of the academy in the same year. From that time onwards, he was greatly involved with organizational and training problems, and was especially concerned with the training of young scientists, the establishment of new science centres of the academy and the decentralization of research throughout the Soviet Union. In 1966, he became editor of the Vestnik of the academy.

Millionshchikov was a keen supporter and participant in the Pugwash movement, attending the first meeting in 1957 and becoming Chairman of the Soviet Pugwash Committee in 1964. In 1967 he became chairman of the Supreme Soviet of the Russian Federated Republic, and in both capacities was in an unusually privileged position for maintaining and strengthening scientific contacts with other countries. As early as 1970 , he spoke publicly in favour of Soviet American cooperation in space.

Millionshchikov's published works are relatively few, but his contribution to research in recent years, although classified, won him Lenin and State Prizes, and many Soviet honours and awards, including the Order of Lenin (four times) and the title of Hero of Socialist Labour (the highest Soviet civil award) in 1967. He also won several awards from other countries and was an honorary member of the Academy of Sciences of the German Democratic Republic and of the American Academy of Arts and Sciences.

\section{Ainouncements}

\section{International Meetings}

September 10-12, First European Fluid Power Conference. (The Secretary, First European Fluid Conference, National Engincering Lab., East Kilbride, Glasgow G75 0QU, Scotland.)

September 10-12, Third Biennial Symposium on Turbulence in Liquids. (Walter Ries, Continuing Education, University of Missouri-Rolla, Rolla, Missouri 65401, USA.)

September 10-12, Conference on Differential Geochemistry and Its Applications in Engineering. (The Secretary and Registrar, Institute of Mathematics and Its Applications, Maitland House, Warrior Square, Southend-on-Sea, Essex SS1 2JY.) September 10-13, First National Quantum Electronics Conference. (Dr R. C. Smith, Honorary Secretary, IOP Quantum Elec- 